\title{
がん疼痛治療と医療用麻薬
}

\author{
鈴木 勉 ${ }^{\dagger}$
}

\section{Treatment of Cancer Pain and Medical Narcotics}

\author{
Tsutomu Suzuki ${ }^{\dagger}$ \\ Department of Toxicology, Hoshi University; 2-4-41 Ebara, Shinagawa-ku, Tokyo 142-8501, Japan.
}

(Received July 8, 2015)

\begin{abstract}
The World Health Organization has reported that when morphine is used to control pain in cancer patients, psychological dependence is not a major concern. Our studies were undertaken to ascertain the modulation of psychological dependence on morphine under a chronic pain-like state in rats. Morphine induced a dose-dependent place preference. We found that inflammatory and neuropathic pain-like states significantly suppressed the morphine-induced rewarding effect. In an inflammatory pain-like state, the suppressive effect was significantly recovered by treatment with a $\kappa$-opioid receptor antagonist. In addition, in vivo microdialysis studies clearly showed that the morphine-induced increase in the extracellular levels of dopamine (DA) in the nucleus accumbens (N.Acc.) was significantly decreased in rats pretreated with formalin. This effect was in turn reversed by the microinjection of a specific dynorphin A antibody into the N.Acc. These findings suggest that the inflammatory pain-like state may have caused the sustained activation of the $\kappa$-opioidergic system within the N.Acc., resulting in suppression of the morphine-induced rewarding effect in rats. On the other hand, we found that attenuation of the morphine-induced place preference under neuropathic pain may result from a decrease in the morphine-induced DA release in the N.Acc with a reduction in the $\mu$-opioid receptor-mediated G-protein activation in the ventral tegmental area (VTA). Moreover, nerve injury results in the continuous release of endogenous $\beta$-endorphin to cause the dysfunction of $\mu$-opioid receptors in the VTA. This paper also provides a review to clarify misunderstandings of opioid analgesic use to control pain in cancer patients.
\end{abstract}

Key words_ cancer pain; narcotics; morphine; psychological dependence

\section{はじめに}

1986 年にモルヒネなどの医療用麻薬をがん疼痛 治療に積極的に使用する世界保健機関（World Health Organization; WHO）方式がん疼痛治療法 (Cancer Pain Relief) が発表され，本法が世界に広 く普及した. 1) 以来約 30 年が経過し, 多くのがん患 者ががんの痛みから解放される時代になってきた。 わが国においても WHO の報告から 3 年遅れた 1989 年に徐放性モルヒネ製剂が発売されてようや く本法が普及するようになった。 しかし，わが国の 国民はアヘン戦争や覚せい剂の乱用問題などの歴史 的背景から麻薬恐怖症（opioid phobia）が根強く

星薬科大学薬品毒性学教室（干142-8501 東京都品川区 荏原 2-4-41)

現所属: ‘星薬科大学薬物依存研究室（干142-8501 東 京都品川区荏原 2-4-41)

e-mail: suzuki@hoshi.ac.jp

本総説は, 平成 26 年度退職にあたり在職中の業績を中 心に記述されたものである.
植え付けられており，さらに武士道などから痛みに 耐えることを美徳とする文化も強く根付いている. これらが相まって，がん患者やその家族が医療用麻 薬に対する誤解や偏見を強く持ち，がんの痛みがと れる時代にもかかわらず，残念ながら医療用麻薬に よる積極的ながん疼痛治療が十分には行われていな いのが現状である。WHO 方式がん疼痛治療法の普 及の障壁となっている医療用麻薬に対する誤解を解 くために，われわれは基礎研究に長年取り組んでき たそそこで，本総説ではわれわれの研究成果を中心 に，がん疼痛治療に医療用麻薬を適切に用いれば薬 物依存が問題になることはないこととそれ以外の医 療用麻薬に対する誤解を解いてみたい.

1. がん治療の現状（がんは治せる時代）

がんの治療効果は診断から一定期間後に生存して いる確率（生存率）で表される。通常，治療後 5 年 経過したときの生存率（5 年生存率）を治癒の目安 として表されている。最近の独立行政法人国立がん 
研究センターがん対策情報センターの統計による と，がんの 5 年生存率は全がんで 1997 年の $61.7 \%$ から徐々に改善し，2005 年には 68.0\%に達してい る. ${ }^{2)}$ 改善率（年率）は約 $0.7 \%$ あり，治療成績が 毎年約 $0.7 \%$ 改善されてきたことになる。すなわ ち, 化学療法, 放射線療法やがんの早期発見技術の 進歩がこのような結果に貢献していると考えられる.

前述のように 2005 年のがん患者 5 年生存率は 68.0\%であるが，同様に約 $0.7 \%$ 改善率（年率） で推移しているならば，2015 年の今日では 5 年生 存率がさらに約 7\%改善されて 75\%程度に向上して いると予想できる，すなわち，がんの多くは治療で きる時代になっていると言える.

\section{2. なぜ, 痛み治療が大切か ?}

淀川キリスト教病院ホスピスが編集した「緩和ケ アマニュアル（第 5 版）」3)によると，死亡時期には 全身倦怠感, 食欲不振, 痛み, 便秘, 不眠, 呼吸困 難, 嘔気・嘔吐, せん妄, 死前喘息, 腹水, 不穏, 消化管閉塞（頻度順）などの身体症状が現れる.こ れらの中で，最期に $60 \%$ 以上の高い頻度で現れる 症状は全身倦怠感, 食欲不振, 痛み, 便秘, 不眠で あった，身体症状の発現時期を見てみると，大変特 徵的な症状が「痛み」であり，他の症状がまだほと んど現れない早期より現れる，多くの身体症状が現 れ出すのが余命 1 力月頃からであり,「痛み」以外 にも全身倦怠感，食欲不振，便秘，不眠などの身体 症状が明確に現れようになる。緩和医療ではがん患 者のこれらの身体症状を可能な限り取り除かなけれ ばならない，特に，痛みは余命 2 力月頃まで前面に 立ち，40\%程度の発現頻度である。したがって，余 命 1-2 カ月頃までは痛みをしっかりコントロールで きれば，がん患者が海外旅行をすることも可能であ る．また，がんの痛みに苦しまされることがなけれ ば，人生最期の大事な時期に「やりたいこと」や 「やらなければならないこと」を行うこともできる. したがって，がんの痛み治療はとても大事な治療で ある。

\section{WHO 方式がん疼痛治療法（いつから始める} のか ?)

1986 年に発表された WHO 方式がん疼痛治療法 はわが国でも 80-90\%除痛できる大変有効な治療法

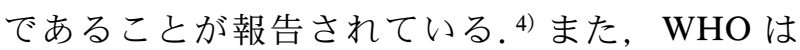
2002 年に「緩和ケアとは生命を脅かす疾患に伴う

問題に直面する患者と家族に対し，疼痛や身体的， 心理社会的，スピリチュアルな問題を早期から正確 にアセスメントし解決することにより，苦痛の予防 と軽減を図り，生活の質（QOL）を向上させるた めのアプローチである」と定義している、緩和ケア は，病気の時期や治療の場所を問わず，いつでもど こでも提供される必要がある。従来，緩和ケアは 「看取りの医療」と考えられがちだつたが，WHO の定義では，「身体や心のつらさ」に焦点があてら れている。これにより，がんが進行した患者だけで なく，がんと診断された患者が可能な限り快適に過 ごすために，がんの痛みを始め，様々な症状を和ら げる緩和治療が，早期から行われることが重要であ ると考えられてきている。一方，わが国のがん対策 基本法（2007 年）では, 生活の維持・向上のため に, 治療の早期から緩和ケアが適切に導入されるこ との重要性が指摘されている，緩和ケアが必要な時 期は，患者・家族がなんらかの苦痛や心配を持ち， 解決が必要になったときであり，そのときが緩和ケ アの開始時期でもある．緩和ケアを実施するか否か は，患者の状態が「終末期」であるから，がん治療 中だから，という状態によって決まるのではなく， 患者に「苦痛」があるか否かで決定する.

近年，脱法ドラッグの乱用による事件や事故が大 きな社会問題となり，「脱法ドラッグ」ではその危 険性が国民に十分に伝わらないとの理由で呼称を広 く募集した。 その結果が大変ショックングな内容で あったので紹介する，その結果は準麻薬（183），廃 人ドラッグ $(140)$, 危険薬物（123），破壊ドラッグ (110)，危険ドラッグ (102)，有害ドラッグ (95), 違法ドラッグ $(87)$, 殺人ドラッグ $(85)$, 幻覚ド ラッグ (85), 錯乱ドラッグ (81) の順であった. この中から，国民に危険性が最も伝わると思われる 呼称として「危険ドラッグ」が選択された. ${ }^{5)}$

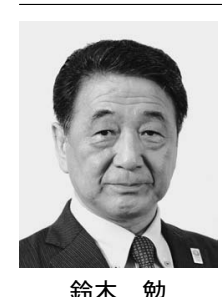

鈴木 勉
1979 年星薬科大学大学院博士課程修 了, 同大学助手, 講師, 助教授を経て, 1999 年教授, 2015 年特任教授 - 名誉教 授. 1984-86 年ミネソ夕大学医学部及 び米国国立薬物乱用研究所研究員. WHO 薬物依存専門委員会委員, 厚労 省薬事・食品衛生審議会指定薬物部会 長等. 日本薬理学会理事, 日本アル コール薬物医学会理事長, 日本緩和医 療薬学会理事長等歴任. 


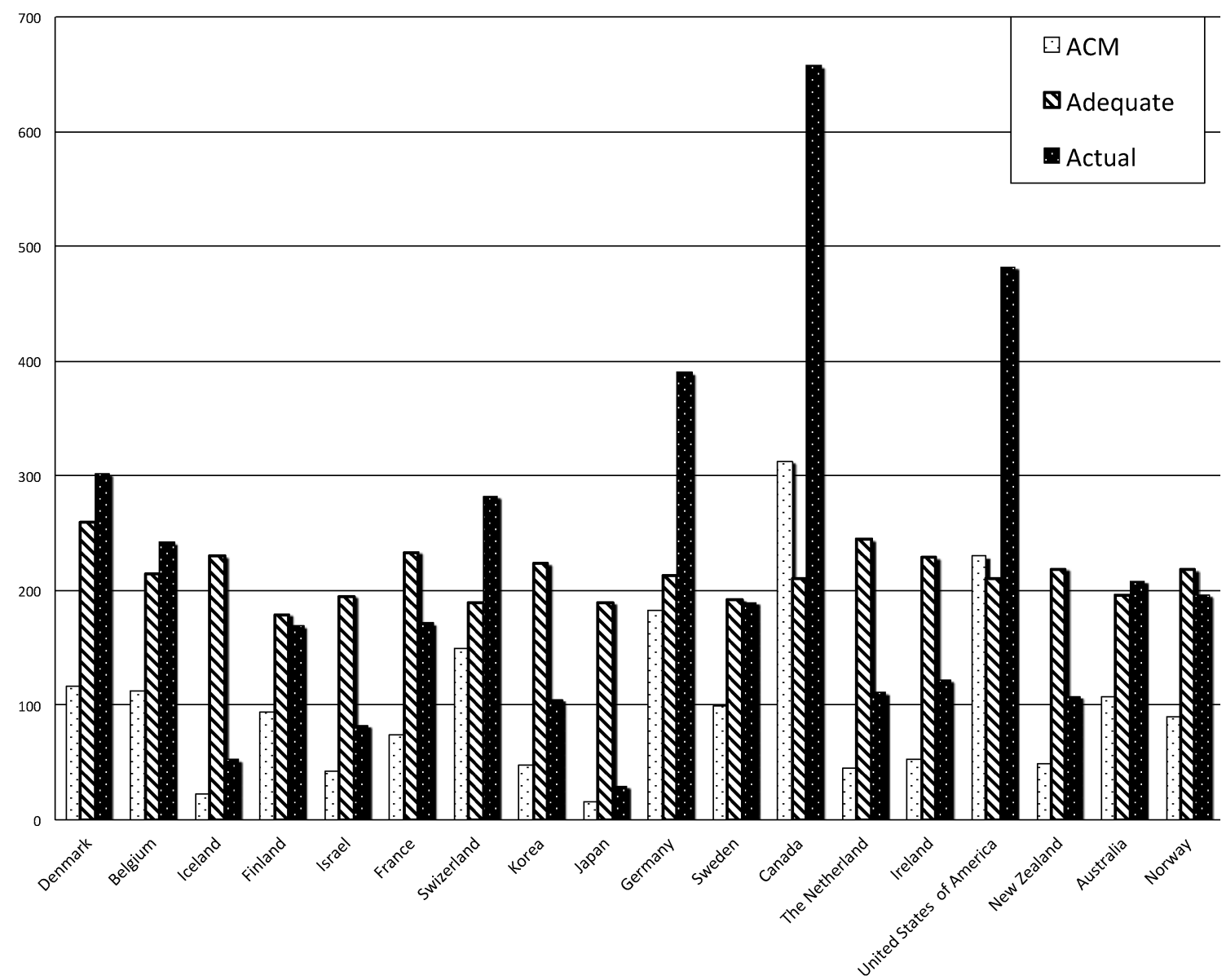

Fig. 1. Adequacy of Opioid Analgesic Consumption at Countries

ACM: Adequacy of Consumption Measure. Adequate consumption calculates needs per capita for relevant strong opioid analgesics based on three major causes of pain (terminal cancer, lethal injuries, and end-stage HIV/AIDS). The method includes consumption figures for morphine, fentanyl, oxycodone, hydromorphone, and pethidine and converts them to morphine equipotency, and converts them to morphine equipotency. Y-axis: ACM 2010 (\%), and adequate and actual (consumption of $\mathrm{mEq}$ in $\mathrm{mg}$ per capita 2010).6)

この調査の中で驚いたことが 1つある。それは危 険性を表す用語として最も多い意見が「準麻薬」で あったことである．国民が「麻薬」をどれだけ恐れ， 怖がっているかが窥える。「準麻薬」であるから， 「麻薬」の次に怖いのが「危険ドラッグ」であると の理解である，当然のことながら，「危険ドラッグ」 はその有効性も安全性も全く検討されていない危険 な化学物質であり，このような「危険ドラッグ」を 口にしたり，吸引したりすることはどんな症状（死 亡も含め）が起きてもおかしくない，大変危険な行 為である。一方，「危険ドラッグ」に対する多くの 国民の意識は「準麻薬」であり，「麻薬」の方が 「危険ドラッグ」よりもつと怖くて危険な薬物と考 えている，すなわち，麻薬恐怖症がいかに多く，か つ強いかを証明する結果ともなつた。

\section{4. 世界でも非常に少ない日本の医療用麻薬の使} 用量

2014 年 Duthey \& Scholten ${ }^{6}$ ) は各国の医療用麻薬 の必要量を，末期がん患者の $80 \%$ と末期エイズ患 者の $50 \%$ は 90 日間，致死障害患者の $15 \%$ は 5 日間 $75 \mathrm{mg} /$ 日/人のモルヒネを使用するとして算出し た。さらに，各国は国際麻薬統制委員会 (International Narcotics Control Board; INCB) に年間の医 療用麻薬の使用量を毎年報告しなければならない. これらのデータから, 各国の医療用麻薬の必要量に 対する実使用量の比率 (充足率) を求めて比較した. その結果, わが国の充足率は $15.54 \%$ であり, 先進 諸国の中でも特に少なく大きな衝撃を受けた（Fig. 1). 最近まで, わが国は少量でありながらもアジア 諸国の中では最も多くの医療用麻薬を使用してき た。しかし最近，韓国の使用量が急に増加して充足 
率が $47 \%$ となり，ヨーロッパの諸国に追いついて いる．わが国も韓国などの取り組みを参考にしなが ら，ホスピスの国，英国における充足率が $66.38 \%$ であることから，英国を当面の目標にしてがん疼痛 治療の推進を図る必要があると考えている。一方, 米国などを中心に，オピオイド鎮痛薬の乱用やオー バー・ドースによる多くの死者が報告されている. そこで，米国とカナダの充足率を見てみると，それ ぞれ 229.65\%，312.56\%であり，必要量の 2-3 倍の 医療用麻薬が消費されており，明らかな使い過ぎで ある. 米国の 2007 年の医療用麻薬のオーバー・ ドースなどによる死者数が約 12000 名に達してお り，深刻な社会問題になっている. ${ }^{7)}$ このように医 療用麻薬の使用量が少なければ，患者が痛みと副作 用に苦しみ，多ければ乱用や死亡事故につながるこ とから, 医療用麻薬の適正使用と乱用防止のバラン スの重要性を肝に命じなければならない.

\section{5. 医療用麻薬を使いたくない理由}

わが国の医療用麻薬の使用量が先進諸国の中で最 も低い原因として，医療用麻薬に対する誤解や偏見 があると思われる． 鈴木の報告 ${ }^{8)}$ によると医療用麻 薬を処方されたくない理由として，「がんとは関係

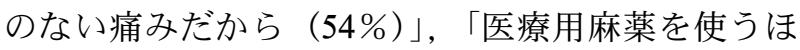

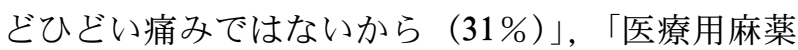
は依存・中毒になるかもしれないから $(26 \%) 」$, 「医療用麻薬は末期の患者に使われるものだから $(18 \%) 」$, 「医療用麻薬を一度使うと, 薬をやめるこ

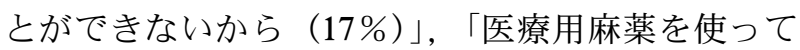

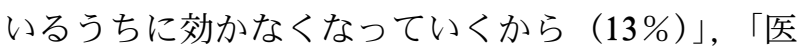
療用麻薬を服用すると命を縮めるかもしれないから $(10 \%) 」$, 「医療用麻薬を使うと抗がん剂の治療がで きなくなるかもしれないから (6\%)」,「その他（2 \%)」が挙げられている。 これらの代表的な誤解や 偏見の第一に，「医療用麻薬を使うほどひどい痛み ではないから」や「医療用麻薬は末期の患者に使わ れるものだから」には「医療用麻薬はがん疼痛治療 の最後の手段だから」という想いがある．第二に， 「医療用麻薬を服用すると命を縮めるかもしれない から」が挙げられる，さらに，最も懸念されている 誤解が, 「医療用麻薬は依存・中毒になるかもしれ ないから」や「医療用麻薬を一度使うと, 薬をやめ ることができないから」などの依存の問題である. そこで, 医療用麻薬に対するこれらの三大誤解につ
いて以下に述べる.

5-1. 医療用麻薬は最後の手段か？ がん患者 はがん疼痛をなかなか受け入れることができずに痛 みを我慢することが多い，WHO 方式がん疼痛治療 法は大変有効な除痛手段であるが，がん患者は「モ ルヒネなどの医療用麻薬で早くから痛みを抑える と，もつと強い痛みに襲われたときに使う鎮痛薬が なくなってしまう」と誤解している，しかし，医療 用麻薬はがん疼痛をとるための最後の手段ではな い.がん疼痛は非薬物療法でもとることができる. 例えば，放射線療法があり，症状緩和を目的とした 場合には照射線量も少なく比較的短期間で（30 Gy $/ 10$ 回/2 週や $8 \mathrm{~Gy} / 1$ 回）終了することも可能であ る. 緩和的放射線治療には禁忌がないと考えられて いるので，がん疼痛治療に広く用いることができ る.さらに，神経ブロックも広く使用されている. 神経ブロックは痛みを伝達する神経そのものを遮断 するため, 一時的であっても確実に除痛が得られ る. 痛みの部位, 範囲, 性質によっては完全除痛を 得ることも可能である. 効果の持続はブロックに用 いる薬物により調節することが可能である。 また, 理学療法もがん疼痛治療に用いられる。理学療法は 痛みをとるだけでなく, 痛みに伴う症状を和らげる ことも目的とされている. 理学療法には運動療法, 温熱療法, 電気刺激療法などがある。運動療法は筋 力増強訓練やストレッチなどにより，筋肉の緊張を ほぐして血流を改善して痛みを緩和する. 温熱療法 は組織を温めて血管を広げ，血流を改善する。ささら に, 電気刺激療法は低周波の電気刺激により, 痛み を伝達する神経の働きを抑える，最後に，補完代替 療法には漢方，鍼尒を中心とした東洋医学が含まれ ている.このように医療用麻薬以外にもがん疼痛を 緩和する方法があり，決して医療用麻薬ががん疼痛 治療の最後の手段ではない.

5-2. 医療用麻薬は寿命を縮めるのか? がん 疼痛治療にモルヒネなどの医療用麻薬を使用する と，寿命が縮むと誤解されていることが多い．これ までのがん疼痛治療は患者ががん疼痛を我慢に我慢 を重ね，最後の最後にモルヒネを使用するため，モ ルヒネを使用後間もなくしてがん患者が亡くなるた めに，モルヒネを使うと寿命が縮むと誤解されるこ とが多くなってしまった。しかし， Lillemore ら99 は膵臓がんの痛みをアルコールによる内臓神経ブ 


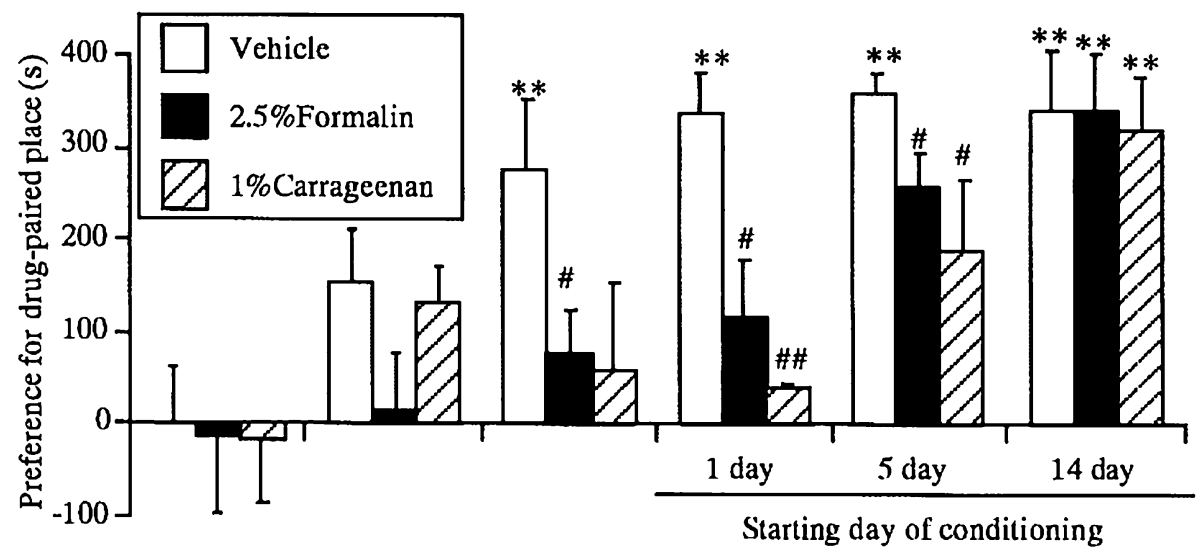

SAL

2

4

8

Morphine dose (mg/kg, i.p.)

Fig. 2. Effect of Inflammation and the Conditioning Period on the Development of the Morphine-induced Place Preference ${ }^{13)}$ ${ }^{* *} p<0.01$; signify conditioning. ${ }^{*} p<0.05,{ }^{*} p<0.01$; signify different from the preference in the vehicle-treated gorup at the respective dose.

ロックで除痛できた患者の余命が生理食塩液を処置 した患者の余命より明らかに長いことを報告してい る.さらに, Wong ら¹0)は stage III と stage IV の がん患者に腹腔叢ブロックと鎮痛薬により除痛を 行って余命を比較したところ，その余命には有意な 差がなかつたことを報告している。これらの報告か ら，モルヒネなどの医療用麻薬を用いてがん疼痛治 療を行ってもがん患者の寿命を縮めることはなく, むしろ逆に延命されることが明らかにされている.

\section{5-3. 医療用麻薬でがん患者は依存になるのか？}

WHO は「幅広い臨床経験によって，鎮痛を目的 としてオピオイド鎮痛薬の投与を受けているがん患 者には精神依存が発生しないことが明らかにされて いる」と報告している. ${ }^{1)}$ 残念ながら，これは臨床 経験であり，実証はなされていなかった。そこで, われわれがこのことを実証すべく，炎症性及び神経 障害性疼痛下における医療用麻薬の精神依存の基礎 研究に取り組んだ。 まず，ホルマリンやカラゲニン により炎症性疼痛モデルラットを作製し, 炎症性疼 痛下におけるモルヒネの精神依存を条件づけ場所嗜 好性試験11,12) に従って評価した。 その結果，炎症性 疼痛下ではモルヒネの精神依存が有意に抑制された (Fig. 2).さらに, この炎症性疼痛が減弱すると, 精神依存の抑制もまた減弱することを合わせて報告 している. ${ }^{13)}$ 本現象はわれわれのグループだけでな $<$, Wade らも薬物自己投与法を用いて，炎症性疼 痛下でフェンタニルの自己投与が抑制されることを 報告している. ${ }^{14)}$ われわれは $\kappa$ オピオイド受容体作
動薬が嫌悪効果を示し，モルヒネの精神依存を抑制 することも既に報告している. ${ }^{15,16)}$ また， $\kappa$ オピオ イド受容体作動薬が中脳辺縁ドパミン神経系の投射 先である側坐核におけるドパミン遊離を抑制す る. ${ }^{17)}$ そこで， $\kappa$ オピオイド受容体拮抗薬ノル・ビ ナルトルフィミン（nor-BNI）を前処置して，炎症 性疼痛下のモルヒネの精神依存を評価したところ, 精神依存の抑制は消失した。 ${ }^{18)}$ 次に，ホルマリン誘 発炎症性モデルラットを用いて中脳辺縁ドパミン神 経系の投射先である側坐核におけるドパミン遊離を マイクロダイアリーシス法に従って検討すると, 正 常ラットでは，モルヒネは中脳辺縁ドパミン神経系 を活性化させて，その投射先である側坐核において ドパミンを遊離させて精神依存を示す。一方, 炎症 性疼痛下ではモルヒネによるドパミン遊離が有意に

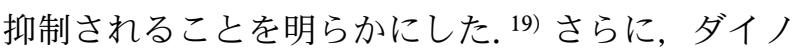
ルフィンの抗体を側坐核に投与して炎症性疼痛によ り遊離されたダイノルフィンを捕獲すると，モルヒ ネにより再びドパミンが遊離され，精神依存を示す

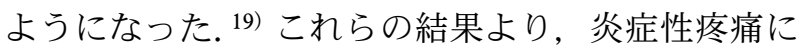
より報酬系である中脳辺縁ドパミン神経系の投射先 である側坐核に介在しているダイノルフィン神経系 が活性化され，ダイノルフィンが遊離される。その 結果, 側坐核に分布している $\kappa$ オピオイド受容体 にダイノルフィンが結合して，モルヒネにより巟進 されるドパミン遊離を抑制する。このような機序 で, 炎症性疼痛下ではモルヒネの精神依存が抑制さ れることを解明した（Fig. 3)。19) 


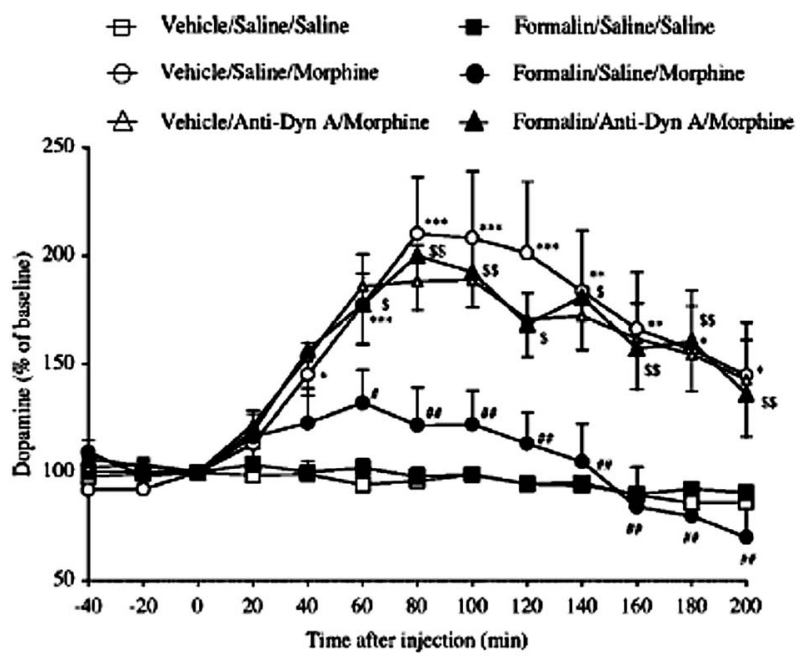

Fig. 3. Effect of Pretreatment with an Antibody Specific to Dynorphin A (Anti-Dyn) into the N.Acc. on the Extractcellular Level of Dopamine in the N.Acc. Induced by Morphine $\left(8 \mathrm{mg} / \mathrm{kg}\right.$, i.p.) under an Inflammatory Pain-like State ${ }^{19)}$ ${ }^{*} p<0.05,{ }^{* *} p<0.01,{ }^{* * *} p<0.001 \mathrm{Vehicle} /$ Saline/Saline group $v s$. Vehicle/Saline/Morphine group. ${ }^{\sharp} p<0.05,{ }^{*} p<0.01$ Vehicle/Saline/Morphine group $v s$. Formalin/Saline/Morphine group. ${ }^{\$} p<0.05,{ }^{\$} p<0.01$ Formalin/Saline/Morphine group vs. Formalin/Anti-Dyn A/ Morphine group.

一方，坐骨神経を半分結紮して作製した神経障害 性疼痛モデル動物20) を用い，モルヒネの精神依存を 評価した。その結果, 神経障害性疼痛下においても 炎症性疼痛下と同様にモルヒネの精神依存は有意に 抑制された（Fig. 4). ${ }^{21-23) ~}$ 神経障害性疼痛下におけ る医療用麻薬の精神依存の形成抑制については, 薬 物自己投与法を用い，モルヒネだけでなく，ヘロイ ン, メサドン, ハイドロモルフォン, フェンタニル についても同様の結果が得られることが報告されて

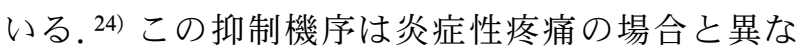
り，神経障害性疼痛では中脳辺縁ドパミン神経系の 起始核である腹側被蓋野において $\beta$-エンドルフィ ンが $\beta$-エンドルフィン含有神経から過剩に遊離さ れ，シナプス後膜の GABA 介在神経上に分布する $\mu$ オピオイド受容体に反応するためにその機能が低 下する (Fig. 5).22,23) その結果, 中脳辺縁ドパミン 神経系の活性化が抑制され，投射先の側坐核におけ るドパミンの遊離が抑制されるため，モルヒネの精 神依存が抑制される。事実, $\beta$-エンドルフィンのノ ックアウトマウスを用いて，側坐核におけるドパミ ン遊離をマイクロダイアリーシス法に従って検討し たところ，野生型が神経障害性疼痛下でモルヒネに よりドパミン遊離が有意に抑制されるのに対して, $\beta$-エンドルフィンのノックアウトマウスは坐骨神経

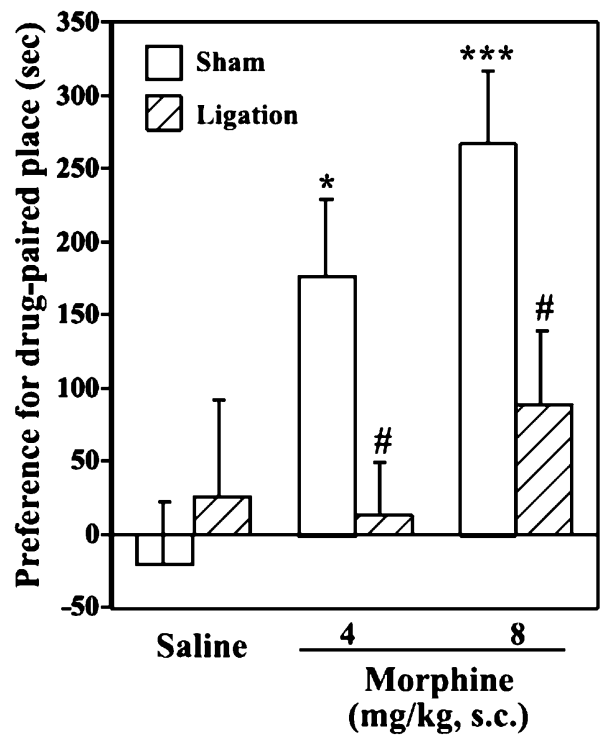

Fig. 4. The Place Preference Produced by Subcutaneous Administration of Morphine $(4$ or $8 \mathrm{mg} / \mathrm{kg})$ in Sham-operated and Sciatic Nerve Ligated Rats Using Conditioned Place Preference Assay ${ }^{21)}$

${ }^{*} p<0.05,{ }^{* * *} p<0.001 v s$. saline groups. ${ }^{*} p<0.05$ vs. sham groups.

を結紮してもドパミンの遊離を示し，そして有意な 精神依存も発現した (Fig. 6). ${ }^{25-27)}$

このようにわれわれは動物実験において炎症性及 び神経障害性疼痛に医療用麻薬の鎮痛用量を投与す れば有意な精神依存が形成されないことを証明し た。すなわち，WHOの「Cancer Pain Relief 」1)で 述べているように，「がん性疼痛に鎮痛目的で医療 用麻薬を使用しても精神依存が問題になることはな い」という臨床経験をわれわれが基礎研究において 実証することができた。このことは，がん患者が医 療用麻薬の依存や中毒を恐れることなく，がん疼痛 治療に医療用麻薬を適切に，かつ積極的に使用し， がん疼痛から解放されるべきであることを示してい る.

6. 医療用麻薬の誤解を払拭するために！（麻薬 教育の重要性)

2007 年のがん対策基本法の施行や日本緩和医療 薬学会の設立により，医学教育や薬学教育への緩和 医療の導入が進み, 医療用麻薬によるがん疼痛治療 の教育が大学教育でもなされるようになってきた.

また, 緩和薬物療法認定薬剂師, 緩和ケア認定看護 師やがん性疼痛看護認定看護師が輩出され，緩和医 療の充実に貢献している。このように，医療者側に 対する医療用麻薬によるがん疼痛治療を含めた緩和 


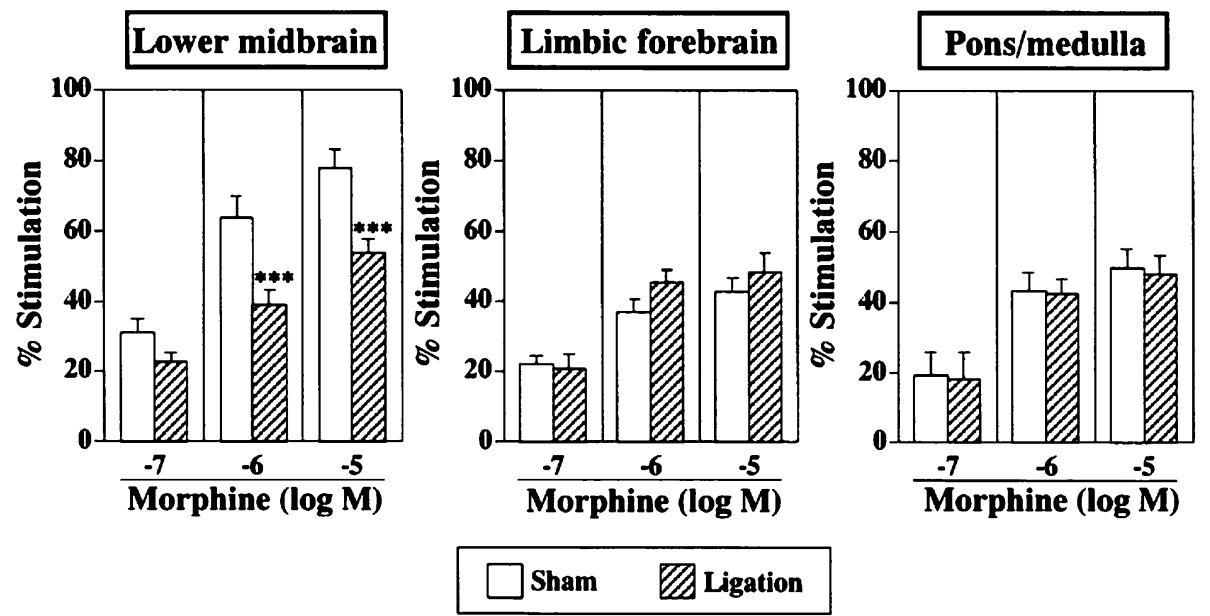

Fig. 5. Effect of Morphine on the Binding of $\left.{ }^{[35} \mathrm{S}\right]$ guanosine- $5^{\prime}-\mathrm{o}-\left(3-\right.$ thio) triphosphate $\left(\left[{ }^{35} \mathrm{~S}\right] \mathrm{GTP} \gamma \mathrm{S}\right)$ to Membranes of the Lower Midbrain (left), Limbic Forebrain (middle) and Pons/Medulla (right) Obtained from Sham-operated and Sciatic Nerve-ligated Mice

${ }^{* * * *} p<0.001$ versus sham groups. ${ }^{22)}$

医療の教育が充実してきている. 一方，患者やその 家族に対する医療用麻薬の教育はほとんどなされて いない，子供達には「ダメ。ゼッタイ」教育がしっ かり行われ, 薬物乱用防止に大いに役立つている.

しかし，モルヒネなどの医療用麻薬のがん疼痛治療 への必要性については全く触れられていないのが現 状である。すなわち,「麻薬は怖いもの, 依存（中 毒）になって，廃人になってしまうもの」というこ とが国民に染み付いてがん年齢を迎えることにな る、そして，がんを患つた患者が初めてモルヒネな どの医療用麻薬を使用する段になって「がんの痛み をとるためにモルヒネなどの医療用麻薬を使っても 依存や中毒にはならないので安心してください」と 医療者から言われてもにわかには信じられないのも よく理解できる。本心では, 「医療用麻薬でも麻薬 だから依存や中毒になってしまうだろう」との誤解 を払拭できずに，いまだにがんの痛みを我慢してい る人が多いと言える。 そこで，このような誤解を払 拭するためには，1 日も早く子供達に不正麻薬の 「ダメ。ゼッタイ」教育とバランスをとりながら, がん疼痛などへの「医療用麻薬の適正使用の必要性」 の教育を並行して行っていく必要性がある.

\section{7. がんの痛みを伝える!}

がん疼痛治療において大切なことは, 痛みのアセ スメントである. ${ }^{28,29)}$ 日本人には「痛みに耐えるこ とが美徳」とする文化 (精神) が根付いているため, 痛みのアセスメントにおいても過少申告することが
多い，さらに，がん患者が痛みを訴えることは，病 状が進行していることを許容することになることか ら，痛みを耐えることにつながる，したがって，患 者と医療者のコミュニケーションをしつかりとり, 双方の信頼関係を構築することが大変重要である. さらに，患者は職種によっても言い易いこと，言い 難いことが異なり, 特に主治医には医療行為全体を 否定するようにも思え，「痛い」とはなかなか言い 難いし，言うにはかなりの勇気が必要である。しか し, 疼痛治療は痛みのアセスメントから始まるの で，がん患者が「痛い」と言い易い環境を作ること が重要である.さらに, 医療者側は疼痛アセスメン トをしっかり行い, その痛みからがん患者を解放し て頂きたい. ${ }^{30,31)}$

\section{8. がん疼痛からの解放}

本稿を執筆している間にも，がん疼痛治療を妨げ る 2 つのことが報道された。 まず，俳優今井雅之氏 が大腸がんで 54 歳という若さで亡くなられた。今 井氏は記者会見で大腸がんの stage IV で闘病して いることを明らかにし，さらに今井氏は「夜中にこ んな痛みと闘うのはつらい」,「モルヒネで殺してく れと言いました, 安楽死ですね」といつたことを発

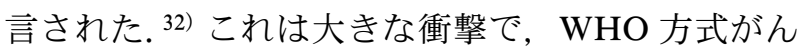
疼痛治療法の第一目標は「睡眠時に痛みで目覚めな い状態」にすることであり, これが達成されておら ず，疼痛治療がなされていなかったことを示してい る.さらに，モルヒネは寿命を縮めることもない 
(A)

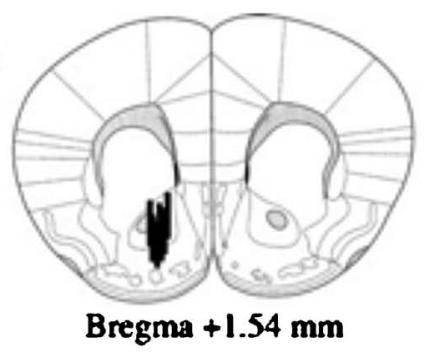

(B)
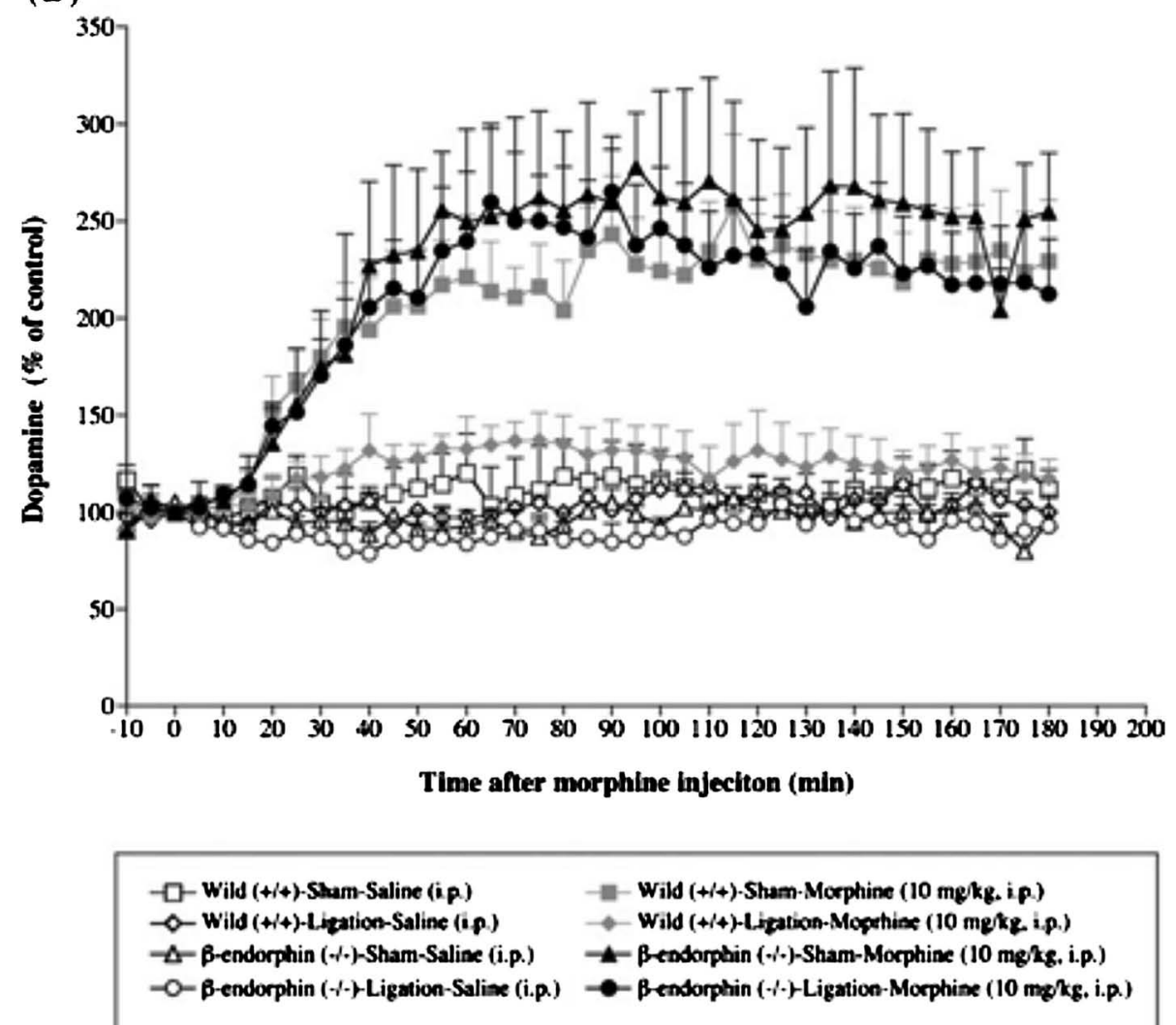

Fig. 6. Change in the Increased Dialysate Dopamine Level Induced by Morphine in Beta-endorphin Knockout $(-/-)$ Mice Localization of microdialysis probe sites in the mouse N.Acc (A). Effects of treatment with morphine on the dialysate dopamine level in the N.Acc. in sham- or nerve-ligated wild-type and these beta-endorphin knockout $(-/-)$ mice $(\mathrm{B})$. Morphine $(10 \mathrm{mg} / \mathrm{kg}$, s.c.) or saline was injected at time 0 . The data are expressed as percentages of the corresponding baseline levels with S.E.M. F $(1,234)=2.824, p<0.0001$; sham-operated wild type mice treated with morphine $v s$. sham-operatedendorphin knockout $(-/-)$ mice treated with morphine. ${ }^{26)}$

し，安楽死をさせる薬でもない，既に，述べたよう に医療用麻薬で疼痛コントロールすることにより, 余命はむしろ延長することが分かっている. ${ }^{9,10)} こ$ のような誤った情報が報道されることはがん患者や ご家族，さらに医療者に大きな負の影響を与えてい る. ${ }^{32)}$

さらに，もう 1 つはトヨタ自動車のジュリー・ハ ンプ常務（2015 年 7 月 2 日辞任）がオキシコドン とアセトアミノフェンの配合錠（パーコセット）を

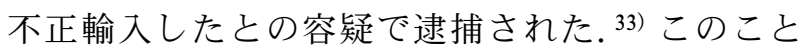
で, 現在がん疼痛治療を受けている患者やご家族に
不安を与え，患者がその使用を独自に中止するケー スが考えられる，そこで，関係機関が急激な中止を 行わないことの啓発や急激に中止した場合には退薬 症候が発現することを周知徹底する必要がある。

このような出来事で，がん疼痛治療や緩和医療が 後退しないようにしてほしい.しかし，これまでも 何回となく，このようなことを繰り返しているの で，マスメディアによる報道のあり方を是非検討し て頂きたい.

おわりに

1986 年の WHO 方式がん疼痛治療法の開発によ 
りがんの痛みはとれる時代に突入した。 また，わが 国において本法に使用できる医療用麻薬は1989年 から 10 年以上に渡ってモルヒネのみであったが, 現在ではフェンタニル，オキシコドン，メサドン, タペンタドールが加わり 5 種類になり，これらをう まく使い熟せば疼痛コントロールの質も向上させる ことができる。しかし，反対にこれらの医療用麻薬 を医師が使いこなすことの困難さも指摘されてきて おり，薬の専門家である薬剤師の活躍の場でもある と思われる。ささらに，医療用麻薬に対する誤解や医 療用麻薬の教育不足などから，わが国の医療用麻薬 の使用量は先進諸国の中で最も少ない. 本稿で述べ たように，医療用麻薬に対する誤解は科学的にも解 明されてきたので，今後教育の充実に努め，すべて のがん患者が痛みから一日でも早く解放されること を念願している.

利益相反 開示すべき利益相反はない.

\section{REFERENCES}

1) World Health Organization, "Cancer Pain Relief,', 2nd ed., 1996.

2) Center for Cancer Control and Information Services, National Cancer Center: 〈http:// ganjoho.jp/public/statistics/pub/statistics01. html $\rangle$, cited 19 August, 2015.

3) Yodogawa Christian Hospital, "Palliative Care Manual," 5th ed., Saishin Igakusha, Osaka, 2008.

4) Takeda F., Pain Clinic, 1, 83-89 (1986).

5) Ministry of Health, Labour and Welfare, 〈 http: / / www.mhlw.go.jp / stf / houdou / 0000051607.html $\rangle$, cited 19 August, 2015.

6) Duthey B., Scholten W., J. Pain Symp. Manage., 47, 283-297 (2014).

7) Okie S., N. Engl. J. Med., 363, 1981-1985 (2010).

8) Suzuki E., Pharma Medica, 32, 115-119 (2014).

9) Lillemoe K. D., Cameron J. L., Kaufman H. S., Yeo C. J., Pitt H. A., Sauter P. K., Ann. Surg., 217, 447-457 (1993).

10) Wong G. Y., Schroeder D. R., Carns P. E., Wilson J. L., Martin D. P., Kinney M. O., Mantilla C. B., Warner D. O., JAMA, 291, 1092-1099 (2004).
11) Suzuki T., Masukawa Y., Misawa M., Psychopharmacology, 102, 438-442 (1990).

12) Suzuki T., Funada M., Narita M., Misawa M., Nagase H., Eur. J. Pharmacol., 205, 8588 (1991).

13) Suzuki T., Kishimoto Y., Misawa M., Life Sci., 59, 1667-1674 (1996).

14) Wade C., Krumenacher P., Kitto K. F., Peterson C. D., Wilcox G. L., Fairbanks C. A., PLoS One, 8 e79239 (2013).

15) Funada M., Suzuki T., Narita M., Misawa M., Nagase H., Neuropharmacology, 32, 1315-1323 (1993).

16) Funada M., Suzuki T., Misawa M., Ann. Psychiat., 5, 223-237 (1995).

17) Narita M., Funada M., Suzuki T., Pharmacol. Ther., 89, 1-15 (2001).

18) Suzuki T., Kishimoto Y., Misawa M., Nagase H., Takeda F., Life Sci., 64, PL1-PL7 (1998).

19) Narita M., Kishimoto Y., Ise Y., Yajima Y., Misawa K., Suzuki T., Neuropsychopharmacology, 30, 111-118 (2005) .

20) Shir Y., Seltzer Z., Neurosci. Lett., 115, 62-67 (1990).

21) Ozaki S., Narita M., Narita M., Iino M., Sugita J., Matsumura Y., Suzuki T., J. Neurochem., 82, 1192-1198 (2002).

22) Ozaki S., Narita M., Narita M., Iino M., Miyoshi K., Suzuki T., Neuroscience, 116, 8997 (2003).

23) Ozaki S., Narita M., Narita M., Ozaki M., Khotib J., Suzuki T., J. Neurochem., 88, 1389-1397 (2004).

24) Martin T. J., Kim S. A., Buechler N. L., Porreca F., Elsenach J. C., Anesthesiology, 106, 312-322 (2007).

25) Niikura K., Narita M., Okutsu D., Tsurukawa Y., Nanjo K., Kurahashi K., Kobayashi Y., Suzuki T., Neurosci. Lett., 433, 54-58 (2008).

26) Niikura K., Narita M., Narita M., Nakamura A., Okutsu D., Ozeki A., Kurahashi K., Kobayashi Y., Suzuki M., Suzuki T., Neurosci. Lett., 435, 257-262 (2008).

27) Niikura K., Narita M., Butelman E. R., Kreek M. J., Suzuki T., Trends Pharmacol. Sci., 31, 299-305 (2010).

28) Japanese Society for Palliative Medicine, "Clinical Guidelines for Cancer Pain Manage- 
ment," Kanehara \& Co., LTD., Tokyo, 2014, pp. 29-36.

29) Japanese Society of Pharmaceutical Palliative Care and Science, "Textbook of Pharmacotherapy in Palliative Medicine,', Nankodo Co., Ltd., Tokyo, 2014, pp. 20-25.

30) Yomiya K., "Clinical Pearls in Palliative Care: You just wanted to know," Nankodo
Co., Ltd., Tokyo, 2011, pp. 56-63.

31) Yomiya K., "Gantotsukannwa no Kusuri ga wakaruhon,' Nankodo Co., Ltd., Tokyo, 2013, pp. 1-24.

32) 〈http://matome.naver.jp/odai/214327808770 $7976001\rangle$, cited 19 August, 2015.

33) 〈http://headlines.yahoo.co.jp/hl?a $=20150701-$ 00000106-jij-bus_all $\rangle$, cited 19 August, 2015. 